\title{
Using CFRP NSM Technique with Roots Planted in Concrete to Strength of Prism Beam for Shear
}

\author{
Douread R. Hassen, Abdul Aziz Abdul Samad, Noridah Binti Mohamad, Alyaa A. Azeez, and Ali Naji \\ Attiyah
}

\begin{abstract}
This paper presents experimental results of four prismatic concrete reinforced beam and strengthened by NSM (Near surface mounted) FRP (Fiber Reinforced Polymer) reinforced technique, with additional roots planted in the concrete. The strengthening technique causes load capacity of beams to increase from $(6 \%-8 \%)$.A decrease in mid-span deflection was also observed from (4\%-5\%).Using this technique gave increasing in flexural beam resistant under the same conditions and this increasing was also noted in shear beam resistant.
\end{abstract}

Index Terms-Prismatic beam, concrete, carbon fiber reinforced polymer, strengthening.

\section{INTRODUCTION}

Many researchers have focused on the importance of bonding and the type of material that used in bonding between concrete and CFRP to form composite Structural section and previous research indicate to use many materials to increase the bonding strength, for examples: Sikadur 30, 31,32 and 330 and other materials. In this paper was used roots technology that existing in the teeth as a way to increase the bond between concrete and carbon fiber reinforced polymer by using NSM technique, and this will positively influence for thinking to use other ways.

Using fiber-reinforced polymer (FRP) was old technique to strength concrete for bridges and building and has been used widely in the last decade.

FRP has been used in different ways and techniques to find a new material that effective and to ensure long service life of the used structure. The near-surface mounted (NSM) was one of innovative ways that was as strengthening techniques style by place FRP reinforcing bars and strips into grooves precut into the concrete cover in the tension region of the strengthened concrete member Raafat ElHacha, Sami H Rizkalla [1].

Shear and flexural strengthening using FRP materials has been the subject of considerable research, mainly on the use of externally bonded laminates and bars. However, internally bonded NSM reinforcement provides a viable alternative with numerous advantages as reported by De Lorenzis and Teng [2], [3]. For example, the internally bonded NSM reinforcement can be more easily anchored

Manuscript received July 15, 2017; revised November 28, 2017.

Douread R. Hassen, Abdul Aziz. Abdul Samad, Noridah Binti Mohamad and Alyaa A.Azeez are with Faculty of Civil and Environmental Engineering, University Tun Hussein Onn Malaysia (UTHM), 86400 Parit Raja, Batu Pahat, Johor, Malaysia (e-mail: dou_444@yahoo.com, azizs@uthm.edu.my, alyaaabdulrazzaq@yahoo.com.) into adjacent structural members, possesses a better resistance to de-bonding, and is particularly more suitable for strengthening negative moment regions of slabs and beams. In addition, it may require less amount of concrete surface preparation as only cutting the grooves is required, without the need for removal of plastering, smoothening of the concrete surface and removal of weak concrete laitance. The NSM reinforcement can also be easily protected by the concrete cover from mechanical damage, fire and vandalism, and the strengthened element is aesthetically unchanged [4, 5]. Internally bonded NSM reinforcement also allows visual inspection of the surface of the concrete to monitor the existing cracks while laminates hide these vital signs. In addition, a direct comparison showed that flexural strengthening using internally bonded reinforcement achieved higher ultimate loads than strengthening using externally bonded reinforcement with the same axial stiffness [6].

\section{EXPERIMENTAL PROGRAM}

Numerous variables affect the behavior of shear strengthened reinforced concrete beams. This study is limited to investigating some of the more significant factors: (1) flexural and shear strengthening prismatic beam by using NSM technique and (2) flexural and shear strengthening prismatic beam by using NSM CFRP bars technique with roots inside concrete. Four prismatic concrete beams were cast and tested. Two p-beam (A1, A2) were strengthened for shear and flexural using NSM reinforcement. Last two $\mathrm{p}$ beams (B1 and B2) also strengthened for shear and flexural with CFRP bars that have roots inside concrete. Hence, four results are reported. The following sections give details of the p-beam specimens as shown in Fig. 1, their instrumentation, testing procedure and results.

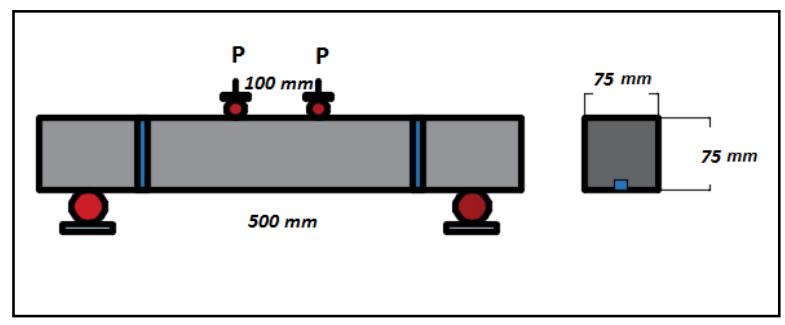

Fig. 1. P-beam scheme.

\section{A. Material Properties}

1) Properties of concrete

A local ready-mix company supplied the concrete, and the target compressive strength was $30 \mathrm{MPa}$. The design slump 
was $75 \mathrm{~mm}$ and the maximum aggregate size was $19 \mathrm{~mm}$. Table 1 summarizes the average values of the results obtained from $150 \mathrm{~mm}$ cubes and standard $100 \times 200 \mathrm{~mm}$ cylinders. The 28-days cylinder strength (fc) as per the relevant ASTM Standards) and the 28-days cube strength (f $\mathrm{cu}$ ) results presented in Table 1 are calculated from the average values of six sample specimens each. The cylinder and cube strength on the day of testing the beams ( $f_{c}^{\prime}$ and $f_{c u}^{\prime}$ Respectively) are calculated from the average of two sample specimens each. As shown in the table, the measured $f_{c}^{\prime}$ was close to the target strength. The compressive strength of the standard cylinders was consistently about $84.4 \%$ of the strength of the $150-\mathrm{mm}$ cube as shown in Table I.

TABLE I: CYLINDER AND CUBES COMPRESSION TEST RESULT
\begin{tabular}{|c|c|c|}
\hline $\begin{array}{c}\text { No. of } \\
\text { Cylinders }\end{array}$ & $\begin{array}{c}\text { Ultimate } \\
\text { Compressive } \\
\text { Strength } f^{\prime}{ }_{c}(\mathrm{MPa})\end{array}$ & $\begin{array}{c}\text { Ultimate } \\
\text { Compressive } \\
\text { Strength } f^{\prime}{ }_{c u}(\mathrm{MPa})\end{array}$ \\
\hline 1 & 24.963 & 29.72 \\
2 & 23.81 & 28.73 \\
3 & 25.89 & 30.52 \\
4 & 25.84 & 30.4 \\
5 & 26.5 & 31.2 \\
6 & 27.75 & 32.67 \\
\hline Average & 25.783 & 30.54 \\
\hline
\end{tabular}

- Properties of CFRP bars

The FRP strengthening was applied using $5 \mathrm{~mm}$ deformed carbon FRP bars and CFRP properties shown in table 2. The typical deformation in some of these bars from testing shown in fig 2 . The CFRP testing for the stressstrain relationship was linear and the modulus of elasticity for CFRP equal to $115 \mathrm{GPa}$ and an ultimate strength of 2300 $\mathrm{MPa}$. The calculated strain at rupture is 0.02 .

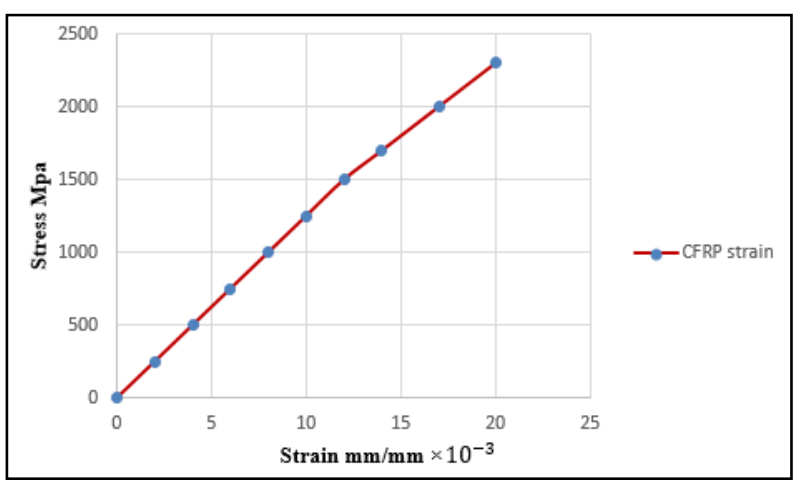

Fig. 2. Stress-strain diagram for FRP bar.

TABLE II: CFRP BAR PROPERTIES

\begin{tabular}{|c|c|c|c|c|}
\hline 范 茍 & 气 & 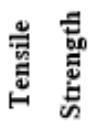 & 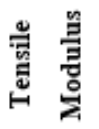 & 总范 \\
\hline$(\mathrm{mm})$ & $(\mathrm{mm} 2)$ & $(\mathrm{MPa})$ & $(\mathrm{GPa})$ & $(\%)$ \\
\hline 5 & 29.9 & 2300 & 115 & 0.02 \\
\hline
\end{tabular}

\section{B. Specimen Preparation}

The preparation of the strengthened p-beams involved: cutting of the grooves on both sides of the beams. After the beams had properly cured, the grooves were cut from concrete face and made some of drilling inside groove as shown in Figure (3). All the grooves had square crosssection, with size of $10 \mathrm{~mm}$. The grooves were cleaned with water jet and air blasted to remove the powdered concrete produced by the cutting process and all the possible loose material .Then the epoxy paste was prepared by mixing the two components (resin and hardener) in 3:1 proportion by volume with a power mixer. The groove was filled half-way with the paste; the CFRP rod was then placed in the groove and lightly pressed. This forced the paste to flow around the bar and fill completely between the bar and the sides of the groove. The groove was filled with more paste and the surface was leveled. The specimens remained in the laboratory environment for four weeks before being tested. After completing the CFRP rods installation, three days before the testing date.

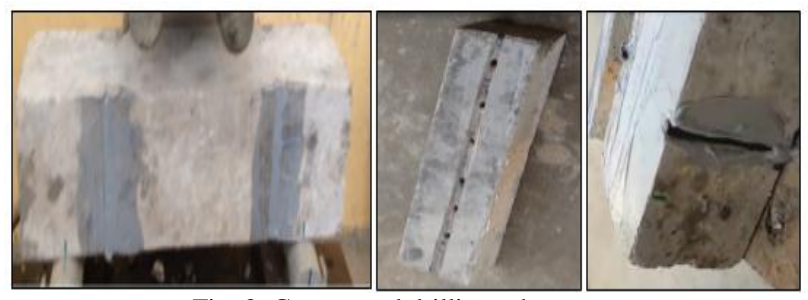

Fig. 3. Groove and drilling scheme.

\section{Test Setup and Procedure}

The beams were tested in a two-point loading setup as shown in Fig.1. The solid rod at the loading and support locations were $20 \mathrm{~mm}$ diameter. The load was applied to fail. The vertical deflections at mid-span of the p- beams were measured using digital dial gauges. The test started with a small pre-load cycle of about $0.5 \mathrm{kN}$ to settle the beam and to maintain positioning before the beginning of the test. Once the readings and observations were taken, the loading was then increased by the next increment and the procedure was repeated.

\section{NSM Shear and Flexural Strengthening}

The NSM shear and flexural strengthening were carried out before the application of the load on the beams. Grooves $20 \mathrm{~mm}$ deep and $20 \mathrm{~mm}$ wide were cut in the cast concrete. Then, the surface of the concrete in the groove was roughened and cleaned. Similar to the procedure used by De Lorenzis and Nanni [3], the epoxy resin was placed to half the depth of the grooves. Then the NSM bar was placed and pressed gently into the epoxy. Then the groove was fully filled with epoxy and the surface was leveled. The epoxy was allowed at least three days to cure before testing the beam specimens. Flexural strengthening of central regions in A1 and A2 by CFRP with out drilling. P-beam (B1 and B2) were strengthened for flexural and shear by using NSM $5 \mathrm{~mm}$ CFRP bars with drilling at $22 \mathrm{~mm} \mathrm{c}$ c. drillings were vertical on concrete side face with $22 \mathrm{~mm}$ depth and $8 \mathrm{~mm}$ diameter. 


\section{EXPERIMENTAL RESULTS}

\section{A. Flexure}

$M_{n}=150 P$

$a=\frac{A_{s f r p} \times f_{y c f r p}}{b_{w} \times f_{c}^{\prime}} \rightarrow a=\frac{19.635 \times 2300}{75 \times 25.783} \rightarrow \mathrm{a}=23.34 \mathrm{~mm}$

$\mathrm{jd}=\left(d-\frac{a}{2}\right) \rightarrow \mathrm{jd}=63.33 \mathrm{~mm}$

$A_{s}^{+}=\frac{M_{n}}{f_{y c f r p^{\times j d}}} \rightarrow M_{n}=2.86 \times 10^{6}$ N.mm,$P=\frac{M_{u}}{150} \rightarrow \mathrm{P}$

$=19.06 \mathrm{kN}$

$P_{t}=38.2 \mathrm{kN}$

\section{B. Shear}

$\frac{M_{u}}{V_{u} \times d}=\frac{2.86 \times 10^{6}}{38.2 \times 10^{3} \times 75}=1 \rightarrow 3.5-2.5 \times \frac{M_{u}}{V_{u} \times d}=1.0<2$.

$V_{C 1}=\left(0.16 \lambda \sqrt{f_{c}}+17 \rho_{w} \frac{V_{u} \times d}{M_{u}}\right) \times b_{w} \times d, \quad \rho_{w}=\frac{A_{s f r p}}{b_{w} \times d}$ $=\frac{19.635}{75 \times 75}=0.0035$,

$f_{c}^{\prime}=25.783 \mathrm{Mpa}$.

$V_{C 2}=0.17 \lambda \sqrt{f_{c}^{*}} \times b_{w} \times d, \quad V_{C 3}=0.29 \lambda \sqrt{f_{c}^{*}} \times b_{w} \times d$

$V_{C 1}=4.9 \mathrm{kN}, V_{C 2}=4.8 \mathrm{kN}, V_{C 3}=8.3 \mathrm{kN}$.

$V_{C}=4.8 \mathrm{kN}$.

$V_{s}=\frac{A_{v f r p} \times f_{f r p} \times d}{s} \rightarrow V_{s}=\frac{2 \times 19.635 \times 2300 \times 75}{75}=39.0 \mathrm{kN}$.

$V_{n}=V_{c}+\stackrel{s}{V_{f r p}} \rightarrow V_{n}=43.8 \mathrm{KN}$.

$P=43.8 \mathrm{kN}$.

The value of $P 1$ s equal to:

$38.2 \mathrm{kN}$ from flexural analysis.

43.8 kN from shear analysis.

The nominal shear strength of an RC beam may be computed by the basic design equation presented in ACI 318-2008 [7]:

$$
V_{n}=V_{c}+V_{s}
$$

In this equation the nominal shear strength is given by the sum of the shear strength of the concrete and the shear strength provided by the steel shear reinforcement. In the case of beams externally strengthened with FRP, the nominal shear strength can be computed by adding a third term to account for the contribution of the FRP reinforcement [7]:

$$
V_{n}=V_{c}+V_{s}+V_{F R P}
$$

by observing both experimental results and the shape of failure occurs in concrete beneath CFRP rod the following equation can be suggested to predict the increasing in ultimate load with acceptable tolerance:

for orientation of CFRP $135^{\circ}$

$$
\mathrm{V}_{\mathrm{FRP}}=0.05 \mathrm{f}_{\mathrm{tFRP}} \frac{\mathrm{b}_{\mathrm{w}} \mathrm{d}}{\mathrm{s}}
$$

For $90^{\circ}$

$$
\mathrm{V}_{\mathrm{FRP}}=0.03 \mathrm{f}_{\mathrm{tFRP}} \frac{\mathrm{b}_{\mathrm{w}} \mathrm{d}}{\mathrm{s}}
$$

where is a tensile stress of CFRP rod. Vc as shear strength of concrete control beam where $\mathrm{f}^{\prime} \mathrm{c}$ is the concrete compressive strength in $\mathrm{MPa}$, bw is the web width in $\mathrm{mm}$ and $d$ the distance from the extreme compression fiber of the cross-section to the centroid of the longitudinal reinforcement, in $\mathrm{mm}$. Table 3 gives a total load closer to the experimental value, so that calculated and experimental values of the shear strength can be compared focusing on the FRP contribution. The prism beams (A1,A2) that strengthened with CFRP bars as a NSM Beams had maximum load equal to $(44 \mathrm{kN}-44.6 \mathrm{kN})$ respectively. On the other hand, the maximum load for prism beams (B1, B2) that strengthened with NSM CFRP bars and using roots

\begin{tabular}{|c|c|c|c|c|c|}
\hline \multirow{2}{*}{ item } & \multicolumn{2}{|c|}{ Theoretical load(Pt) } & \multirow{2}{*}{$\begin{array}{c}\text { Experiential } \\
\text { load }(\mathrm{Pe})\end{array}$} & \multirow{2}{*}{$\% \mathrm{Pt}($ shear $) / \mathrm{Pe}$} & \multirow{2}{*}{$\% \mathrm{Pt}($ flexure $) / \mathrm{Pe}$} \\
\hline & Shear & Flexure & & & \\
\hline $\mathrm{Al}$ & 43.8 & 38.2 & 44.0 & $99.5 \%$ & $86.82 \%$ \\
\hline $\mathrm{A} 2$ & 43.8 & 38.2 & 44.6 & $98.2 \%$ & $85.65 \%$ \\
\hline $\mathrm{B} 1$ & 43.8 & 38.2 & 45.8 & $95.6 \%$ & $83.40 \%$ \\
\hline B2 & 43.8 & 38.2 & 46.3 & $94.6 \%$ & $82.50 \%$ \\
\hline
\end{tabular}
technique was $(45.8 \mathrm{kN}-46.3 \mathrm{kN})$ respectively with increased $(6 \%-8 \%)$.

TABLE III: THEORITICAL AND EXPERIMENTAL LOAD

\section{Load-mid Span Deflection}

Under different stage of loading the mid span deflection for tested specimens were recorded and the following notes were registered:

a. At beginning of loading, load-deflection curves approach to be straight line.

b. Ultimate load and mid span deflection for beams (B1,B2)Strengthened with NSM CFRP that ones have roots in concrete were higher compared with control beams $(\mathrm{A} 1, \mathrm{~A} 2)$ without roots as shown in figure 4.

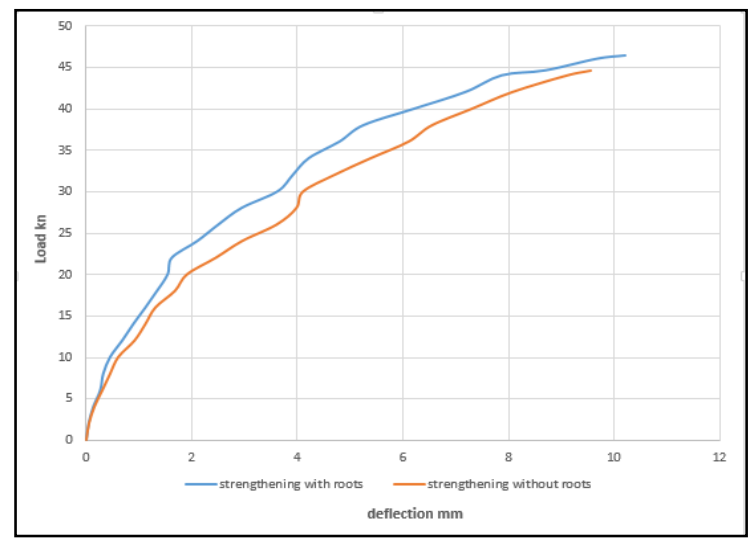

Fig. 4. Mid span deflection for strengthened P-beam.

\section{CONCLUSIONS}

The NSM strengthening way increased the capacity of the test regions to levels, which caused yielding in the longitudinal reinforcement in these regions and hence significantly improved their ductility. The most relevant conclusions of the present work can be summarized as follows:

The use of NSM FRP rods with roots that install in concrete is an effective technique to enhance the load capacity of P-beams. In absence of NSM FRP rods with 
roots, an increase in load capacity as high as 6-8\% with respect to the control beam could be obtained;

Experimental shear load increasing was from $4 \%-5.1 \%$ when the P-beam was strengthened with roots and experimental shear value for P-beam were larger than theoretical flexural results from $0.5 \%-5.4 \%$. On the other hand, the length of root was $25 \mathrm{~mm}$ with $22 \mathrm{~mm}$ spacing .Length and Spacing of roots were effective parameters that will be changed to get deferent result when using roots technique. The experimental results for P-beam were bigger than theoretical flexural results from $13.18 \%$ $17.5 \%$.

At same load $(44.6 \mathrm{kN})$; the prism beams (A1, A2) gave deflection smaller than (B1, B2). The P-beams (A1,A2) have crack width and thickness of splitting area were smaller than P-beams (B1,B2) and that led to using drilling as roots for CFRP increase resistance of composite section and bond between concrete and CFRP.

\section{ACKNOWLEDGMENT}

The authors would like to thank to University Tun Hussein Onn Malaysia (UTHM) for sponsoring this work and my supervisor Prof. Ir. Dr. Abdul Aziz Bin Abdul Samad.

\section{REFERENCE}

[1] R. El-Hacha and S. H. Rizkalla, "Near-surface-mounted fiberreinforced polymer reinforcements for flexural strengthening of concrete structures," Structural Journal, vol. 101, no. 5, pp. 717-726, 2004.

[2] L. D. Lorenzis and A. Nanni, "Shear strengthening of reinforced concrete beams with near-surface mounted fiber-reinforced polyme rods," ACI Structural Journal, vol. 98, no. 1, pp. 60-68, 2001.

[3] D. L. Lorenzis and J. Teng, "Near-surface mounted FRP reinforcement: An emerging technique for strengthening structures," Composites Part B: Engineering, vol. 38, no. 2, pp. 119-143, 2007.

[4] A. Palmieri et al., "Fire testing of RC beams strengthened with NSM reinforcement," in Proc. 10th International Symposium FiberReinforced Polymer Reinforcement for Concrete Structures, Ghent University, Department of Structural engineerin, 2011.

[5] K. Rahal, "Near surface mounted shear strengthening of reinforced concrete beams," American Concrete Institute, Special Publication.

[6] K. N. Rahal and H. A. Rumaih, "Tests on reinforced concrete beams strengthened in shear using near surface mounted CFRP and steel bars," Engineering Structures, vol. 33, no. 1, pp. 53-62, 2011.

[7] A. Committee et al., "Building code requirements for structural concrete (ACI 318-08) and commentary," American Concrete Institute, 2008.

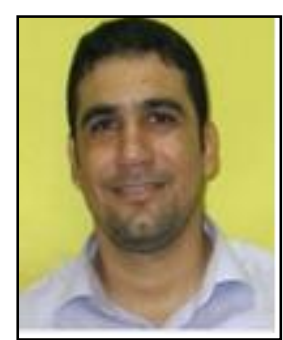

Douread Raheem Hassen is with Faculty of Civil and Environmental Engineering, University Tun Hussein Onn Malaysia (UTHM), 86400 Parit Raja, Batu Pahat, Johor, Malaysia. $\mathrm{He}$ was $\mathrm{PhD}$ student and lecture at Iraqi Ministry of Education since Dec. 15, 1980 in Kufa university, Iraq. He published elelven papers (4 journals and conference ).

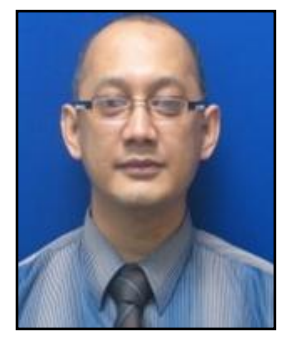

Abdul Aziz Bin Abdul Samad is with Faculty of Civil and Environmental Engineering, University Tun Hussein Onn Malaysia (UTHM), 86400 Parit Raja, Batu Pahat, Johor, Malaysia.

His designation is VK6 - professor and his field (KPT) is engineering sciences / civil engineering; His field of specialization (KPT) is structural engineering.

Abdul Aziz Abdul Samad is a professor in structural engineering and has more than 25 years of teaching, research and administrative experiences. His research interests is in the area of strengthening and repair of damage structure ,precast concrete technology, interlocking load bearing hollow block, concrete fatigue and concrete impact. He has published more than 90 international journal and conferences papers worldwide.

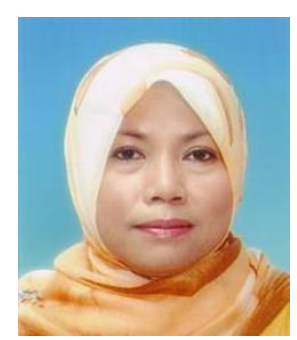

Noridah Binti Mohamad is with Faculty of Civil and Environmental Engineering, University Tun Hussein Onn Malaysia (UTHM), 86400 Parit Raja, Batu Pahat, Johor, Malaysia.

Her designation is DS54 - Profesor Madya. Noridah Mohamad is an associate professor at faculty of Civil and Environmental Engineering and has supervised more than 50 undergraduate students in their final year project, and 16 postgraduate students in their Master and $\mathrm{PhD}$

work

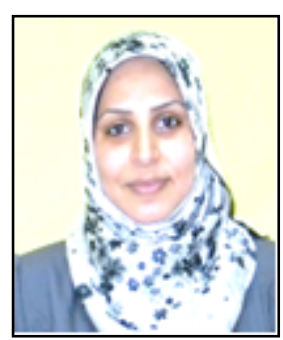

Alyaa Abdulrazzaq Azeez is with Faculty of Civil and Environmental Engineering, University Tun Hussein Onn Malaysia (UTHM), 86400 Parit Raja, Batu Pahat, Johor, Malaysia. She was PhD student in UTHM and lecturer at Iraqi Ministry of Education since Jan. 3, 1986 in Kufa university, Iraq. She published Eleven papers (2 journals and conference).

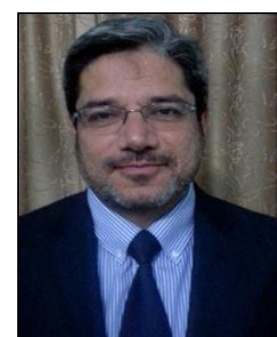

Ali Naji Attiyah is with Faculty of Civil Engineering, University of Kufa, Iraq

Since Dec. 15, 1980, Ali Naji Attiyah is an assistant prof in structural Engineering and and has more than 21 years of teaching, research and administrative experiences. $\mathrm{He}$ is also Leader of Institute ACI Iraq Chapter. He joined the program of UNESCO to rehabilitation of Higher Education in Iraq, which was focused on engineering education. 